\section{小豆ポリフェノールの単回および継続投与が 血中グルコース濃度に及ぼす影響}

小嶋道之 ${ }^{\S}$, 西 繁典, 齊藤優介, 弘中和憲, 小疇＼cjkstart浩，前田龍一郎*

帯広畜産大学食料生産科学

*帯広畜産大学基礎獣医学

Effects of Short-Term and Continuous Administration of Adzuki Polyphenol on Blood Glucose Concentration

Michiyuki Kojima $^{\S}$, Sigenori Nishi, Yusuke Saito, Kazunori Hironaka, Hiroshi Koaze and Ryuichiro Maeda*

Food Production Science, Obihiro University of Agriculture and Veterinary Medicine,

11, Nishi-2-sen, Inada-cho, Obihiro 080-8555

* Basic Veterinary Science, Obihiro University of Agriculture and Veterinary Medicine,

11, Nishi-2-sen, Inada-cho, Obihiro 080-8555

Mice which were tube-administered a single dose of Adzuki polyphenol (APP) showed significantly lower blood glucose levels than the control group after feeding with potato starch, saccharose or maltose. However, no significant differences between the experimental and control groups were observed when glucose was given to the mice. When approximately $40 \%$ of the single-dose amount of APP was administered to mice daily for two weeks before feeding them with saccharose, blood glucose levels were significantly lower in the experimental group than in the control group. In streptozotocin-induced diabetic mice (STZ-DM), blood glucose levels after saccharose ingestion were significantly lower in mice which were administered a single dose of APP than in control mice. Also, in vitro experiments showed that $\alpha$-amylase and $\alpha$-glucosidase activities were suppressed depending on the concentration of the APP dose, and that when the APP-E and APP-M subfractions of APP were added to enzyme solutions, APP-M suppressed the activity of $\alpha$ amylase and $\alpha$-glucosidase. These results indicate that the suppression effect of APP-M on blood-sugar levels may be attributed to the suppression of activity of glycolytic enzymes.

(Received Jul. 19, 2006 ; Accepted Oct. 16, 2006)

Keywords : postprandial blood glucose, adzuki polyphenol, $\alpha$-amylase, $\alpha$-glucosidase, inhibition

キーワード : 食後血糖值, 小豆ポリフェノール， $\alpha$-アミラーゼ,

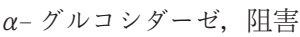

食事として摂取したデンプンやショ糖などは，唾液や膵

于080-8555 帯広市稲田町西 2 線 11 番地

* $=080$-8555 帯広市稲田町西 2 線 11 番地

\&連絡先 (Corresponding author), kojima@obihiro.ac.jp
液から分泌される $\alpha-$ アミラーゼや小腸微柔毛の膜酵素で ある $\alpha$-グルコシダーゼ等の働きにより単糖に分解後，小 腸から吸収され，生体のエネルギー代謝に利用されてい る。通常，食後に上昇した血糖值は，恒常性維持作用によ りすみやかに一定值まで低下する。しかし，糖尿病もしく はその予備軍の人は，食事による急激な血糖值上昇やその 後の血中グルコース代謝不良などにより高血糖状態が継続 し, 網膜症, 神経症および腎障害などの糖尿病二次症状を 引き起こす。このように血糖值の恒常性維持作用は, 糖尿 病や生活習慣病の改善に重要な項目の一つと考えられ, 血 糖值改善作用のある植物成分の探索が進められている。こ れまでにグァバ葉やマテ葉の水抽出液122), 緑茶カテキンや ポリフェノール ${ }^{344)}$ 抢よびイチョウ葉フラボノイド5), 白イ ンゲン豆の $\alpha-$ アミラーゼインヒビター ${ }^{6)}$ などに血糖值改 善作用のあることが報告されている. 本研究では, 抗酸化 活性や肝臟保護作用 7 など機能性の高い食品素材 ${ }^{8}$ である 小豆のポリフェノールをマウスに継続的および単回投与し た時の血糖值に及ぼす影響および小豆ポリフェノール （APP）の糖分解酵素活性（in vitro 実験）に及ぼす影響を 明らかにした。

\section{1. 実験方法}

(1) APP と亜画分の調製

APP の調製および定量は前報と同様の方法で行った また，APP はゲルろ過カラムであるセファデックス LH20 （ファルマシア社製）に供して，エタノールで溶出した APP-E，その後にメタノールで溶出した APP-M の各濃縮 物む，酵素活性抑制実験の試料之して用いた。

(2) APP の継続的及び単回投与

マウスは，市販の固形飼料 CE-2（日本クレア）と自由給 水で飼育し，その取り扱いは Guide for the Care and Use of Laboratory Animals に従った。APP 継続投与実験で は，10 週齢の dd Y 雄マウス（チャールズ・リバーより購 入）を一週間の馴化後に使用した。APP 溶液はポリフェ ノール量 $64 \mathrm{mg} / \mathrm{kg} / \mathrm{d}$ を毎朝 10 時頃, 2 週間継続してゾ ンデ投与した。最終日の 17 時から 16 時間絶食させ， 0.5 $\mathrm{ml}$ のショ糖 $(2.0 \mathrm{~g} / \mathrm{kg}$ 体重) 水溶液をマウスの胃にゾンデ 投与して, その後の血糖值変動を測定した.

単回投与実験には，7週齢の ddY 雄マウス（チャール ズ・リバーより購入）を一週間の馴化後に使用した。 16 時 間絶食させたマウスに，ポリフェノール $168 \mathrm{mg} / \mathrm{kg}$ 体重 に調製した $0.5 \mathrm{ml}$ の APP 水溶液を胃にゾンデ投与し， 30 分後に $0.5 \mathrm{ml}$ の 3 種類の糖水溶液（各 $2.0 \mathrm{~g} / \mathrm{kg}$ 体重に調 製）；ジャガイモデンプン液，マルトース液掞よびグル コース液を胃にゾンデ投与して，その後の血糖值変動を測 定した。また， 4 週齢のマウスにストレプトゾトシン（65 $\mathrm{mg} / \mathrm{kg}$ 体重）を皮下注射 ${ }^{9)} し て ， 4$ 週間後に測定した血糖 值が $250 \mathrm{mg} / \mathrm{dl}$ 以上のマウスをストレプトゾトシン誘発 糖尿病マウス（STZ-DM）として使用した. $0.5 \mathrm{ml}$ の APP 
水溶液（ポリフェノール $168 \mathrm{mg} / \mathrm{kg}$ 体重）を STZ-DM の 胃にゾンデで単回投与し，30 分後に $0.5 \mathrm{ml}$ のショ糖液 $(2.0 \mathrm{~g} / \mathrm{kg}$ 体重に調製) を胃にゾンデ投与して，その後の血 糖值变動を測定した. 年齢/性をマッチさせた対照 (CONT) マウスをコントロール群とした。

(3) 血中グルコース濃度の測定

糖水溶液を投与後, 傷をつけたマウス尾端より 15 分間 隔で採取した血液をプレシジョン電極に少量取り, プレシ ジョン QID（ロート製薬）を用いてグルコース濃度を測定 した.

(4) アミラーゼおよびグルコシダーゼ活性の測定 ${ }^{3)}$

市販の豚膵臓由来 $\alpha-$ アミラーゼ酵素粉末（EC 3.2.1.1，

SIGMA） $1 \mathrm{mg}$ は, $10 \mathrm{ml}$ のリン酸カリウム緩衝液（ $\mathrm{pH}$ 6.7）を加え酵素液とした。 また, 普通食 CE-2 を 2 週間与 えた 13 週齢のマウス小腸内容物は 5 倍量のリン酸カリウ ム緩衝液（pH 6.7）を加えてホモジナイズ後，470xgで 3 分間遠心し，その上清をリン酸カリウム緩衝液（ $\mathrm{pH}$ 6.7） で 200 倍に希釈して実験に用いた， $\alpha$-アミラーゼ活性の 測定は以下のように行った。すなわち， $2.5 \mathrm{ml}$ の $0.5 \%$ 水 解デンプン (和光純薬) 溶液, $1 \mathrm{ml} 0.1 \mathrm{M}$ リン酸緩衝液 (pH 6.7)， $500 \mu 1$ の 1\% 塩化ナトリウム溶液を試験管に加 えて反応混液を作成した。 また，別のチューブに $100 \mu 1$ の $\alpha-$ アミラーゼ溶液と同量の APP 溶液（最終濃度 $10 \sim 45$ ppm に調製）むしくは蒸留水（コントロール）の酵素混合 液を作り, $37^{\circ} \mathrm{C}$ でプレインキュベートした。続いて $4 \mathrm{ml}$ の反応混液とプレインキュベートした $200 \mu 1$ の酵素混合 液を合わせて， $37^{\circ} \mathrm{C}, 10$ 分間インキュベートした. $500 \mu 1$ の $2 \mathrm{M}$ 水酸化ナトリウム水溶液を加えて反応を停止して, $500 \mu 1$ の $1 \%$ ジニトロサリチル酸水溶液を加え沸騰浴中で 10 分間加熱発色後, $540 \mathrm{~nm}$ の吸光值から還元糖量を測定 し，アミラーゼ活性を算出した。

市販の酵母由来 $\alpha$-グルコシダーゼ (EC 3.2.1.20, SIGMA) 粉末 $3 \mathrm{mg}$ は, $10 \mathrm{ml}$ のリン酸カリウム緩衝液（pH 6.7）を 加えて酵素液とした。 また，マウス小腸粘膜に 4 倍量のリ ン酸緩衝液（pH 6.8）を加えてホモジナイズ後, $470 \mathrm{xg}$ で 3 分間遠心し, その上清を酵素液として用いた。 $\alpha-$ グルコ シダーゼ活性の測定は以下のように行った。試験管に 680 $\mu 1$ の蒸留水, $100 \mu 1$ の $0.4 \mathrm{M}$ ショ糖水溶液, $800 \mu 1$ の $0.1 \mathrm{M}$ リン酸緩衝液（pH 6.8）, 220 시 の $1 \%$ 塩化ナトリウム溶液 を加えた反応混液を作成した。また，別のチューブに 200 $\mu 1$ の $\alpha$-グルコシダーゼ溶液と $100 \mu 1$ の APP 溶液（最終 濃度 $2.5 \sim 25.0 \mathrm{ppm}$ に調製）あしくは蒸留水（コントロー ル）を加えて作成した酵素混合液は， $37^{\circ} \mathrm{C}$ でプレインキュ ベートした. 続いて $1.8 \mathrm{ml}$ の反応混液と $300 \mu 1$ の酵素混合 液を合わせて, $37^{\circ} \mathrm{C}, 30$ 分間反応後, アミラーゼ活性と同 様の方法により活性を算出した。

(5) 統計処理

それぞれのデータは平均土標準偏差で表した。デー夕間
の有意差検定は T-test を用い， $p<0.05$ を有意とした。

\section{2. 実験結果および考察}

(1) APP の継続投与および単回投与が血中グルコース 濃度に及ぼす影響

マウスに APP 2 週間継続投与しても, 体重と肝臓重 量の有意差は認められず，また肝臓障害の指標である血中 のラクトースデヒドロゲナーゼ, グルタミン酸オキザロ酢 酸トランスアミナーゼ，グルタミン酸ピルビン酸トランス アミナーゼ, アルカリフォスファターゼ, コリンエステ ラーゼなどの各種酵素活性值にも有意差は認められなかっ た．また，APP の単回投与においても，上記の血清指標に 有意差は認められなかった。

マウスにAPPを 2 週間継続投与もしくは単回投与し て, ショ糖水溶液を添加した場合，ともに血糖值の上昇速 度および血糖最高值はコントロールマウスのそれらよりも 有意に低い值を示した (Table 1). APP の継続投与量は単 回投与量の約 $40 \%$ 量を用い，単回投与量はグァバ葉熱水 抽出物やイチョウ葉抽出物で効果が報告されている量を目 安に決定した ${ }^{1) 5}$. また APP を単回投与して, ジャガイモ デンプン，マルトースおよびグルコースの糖水溶液を添加 した時の血糖最高值は, 前 2 者では有意に抑制された。し かし，グルコースを与えた場合にはコントロールのそれと ほぼ同程度であった（Table 2)，この結果から，APPによ る血糖值の上昇抑制は，デンプン，ショ糖およびマルトー スの酵素分解を抑制することにより起きているため, グル コース投与では効果がみられないものと推察した.

STZ-DM にAPP を単回投与して, ショ糖水溶液を投与 した時の血糖值上昇は，有意に抑制された（Table 1). STZ-DM は, 膵臓ランゲルハンス島の B 細胞が脱落した ことにより起こる 1 型糖尿病 ${ }^{9}$ 症状を示すので, 血中イン スリン濃度はかなり低レベル（未測定）と推測される。こ の結果から，APP はインスリン分泌に作用するのではな く, ショ糖の消化・吸収を抑制することにより血糖值の上 昇抑制が起きていると推察した ${ }^{10)}$.

また，APP を単回投与した通常マウスに，ショ糖，マル トースおよびグルコースを与えた場合，投与 30 分後に血 糖最高值を示し，ジャガイモデンプン水溶液を与えた場合 は，投与後 60 分に示した. しかし，APP を 2 週間継続投 与したマウスにショ糖水溶液を与えた場合の血糖最高值は 60 分後に認められ, 単回投与の場合よりあ 30 分遅延して いた.この結果は, APP の継続投与は, 糖の吸収機構に影 響を与えることを示唆するすのと考えられる. 茶力テキン 類には, インスリン活性 ${ }^{1112)}$ やグルコース輸送タンパク質 (GLUT) の発現量 ${ }^{13)}$ に影響を及ぼすことが報告されてい る. APP 継続投与の場合については, 糖の吸収機構, イン スリン活性や GLUT 発現量に及ぼす影響など今後さらに 検討する必要があると考えている。

（2）APP の糖分解酵素活性に及ぼす影響 
Table 1 Blood glucose levels $(\mathrm{mg} / \mathrm{dl})$ in mice undergoing continuous and short-term administration of APP after feeding with sucrose

\begin{tabular}{|c|c|c|c|c|c|c|}
\hline \multirow{2}{*}{$\begin{array}{l}\text { Time } \\
(\min )\end{array}$} & \multicolumn{2}{|c|}{$\mathrm{CAM}^{1}$} & \multicolumn{2}{|c|}{ STAM $^{2}$} & \multicolumn{2}{|c|}{ STAM (STZ-DM) $)^{3}$} \\
\hline & CONT & APP & CONT & APP & CONT & APP \\
\hline 0 & $77.8 \pm 28.8$ & $73.2 \pm 9.0$ & $92.8 \pm 16.2$ & $108.0 \pm 23.3$ & $93.3 \pm 41.3$ & $88.5 \pm 18.0$ \\
\hline 15 & $160.7 \pm 39.4$ & $112.3 \pm 15.5^{*}$ & $226.1 \pm 36.8$ & $166.4 \pm 52.4^{*}$ & - & - \\
\hline 30 & $210.5 \pm 66.7$ & $144.7 \pm 12.7^{*}$ & $219.5 \pm 38.0$ & $171.8 \pm 35.6^{*}$ & $297.5 \pm 36.1$ & $190.3 \pm 46.6^{*}$ \\
\hline 60 & $175.7 \pm 62.1$ & $173.8 \pm 14.1$ & $178.1 \pm 40.2$ & $141.0 \pm 17.6^{*}$ & $307.8 \pm 55.0$ & $218.3 \pm 68.9^{*}$ \\
\hline 120 & $123.3 \pm 38.4$ & $107.2 \pm 15.0^{*}$ & $138.9 \pm 35.1$ & $97.6 \pm 21.5^{*}$ & $280.0 \pm 90.7$ & $167.3 \pm 79.3$ \\
\hline
\end{tabular}

Abbreviations : CAM, continual administration mice ; STAM, short-term administration mice ; STAM (STZDM), short-term administration and streptozotocin diabetic mice; CONT, control; APP, Adzuki polyphenol.

${ }^{1}$ Values are means \pm standard deviations for 6 mice.

${ }^{2}$ Values are means \pm standard deviations for 12 mice.

${ }^{3}$ Values are means \pm standard deviations for 4 mice of cardioprotection by streptozotocin-induced diabetes. ${ }^{*} p<0.05$.

Table 2 Blood glucose levels $(\mathrm{mg} / \mathrm{dl})$ in mice undergoing temporary daily administration of APP after feeding with starch, maltose or glucose

\begin{tabular}{|c|c|c|c|c|c|c|}
\hline \multirow{2}{*}{$\begin{array}{l}\text { Time } \\
(\min )\end{array}$} & \multicolumn{2}{|c|}{ Starch administration } & \multicolumn{2}{|c|}{ Maltose administration } & \multicolumn{2}{|c|}{ Glucose administration } \\
\hline & CONT & APP & CONT & APP & CONT & APP \\
\hline 0 & $67.3 \pm 14.2$ & $52.3 \pm 15.6$ & $83.3 \pm 22.8$ & $75.5 \pm 5.4$ & $50.0 \pm 12.3$ & $50.7 \pm 23.2$ \\
\hline 30 & $178.7 \pm 10.8$ & $141.0 \pm 8.2^{*}$ & $245.8 \pm 34.0$ & $193.8 \pm 9.4^{*}$ & $180.0 \pm 26.1$ & $170.7 \pm 47.1$ \\
\hline 60 & $201.3 \pm 10.0$ & $141.3 \pm 34.0^{*}$ & $168.0 \pm 15.4$ & $138.0 \pm 22.5^{*}$ & $123.3 \pm 45.0$ & $128.0 \pm 25.1$ \\
\hline 120 & $106.3 \pm 12.7$ & $76.3 \pm 14.0^{*}$ & $89.5 \pm 22.6$ & $78.5 \pm 31.0$ & $57.3 \pm 25.0$ & $56.7 \pm 10.7$ \\
\hline
\end{tabular}

Abbreviations : CONT, control ; APP, Adzuki polyphenol.

${ }^{1}$ Values are means \pm standard deviations for 4 mice.

Sugar dosage was $2 \mathrm{~g} / \mathrm{kg}$ weight. Adzuki polyphenol dosage was $250 \mathrm{mg} / \mathrm{kg}$ weight. ${ }^{*} p<0.05$.
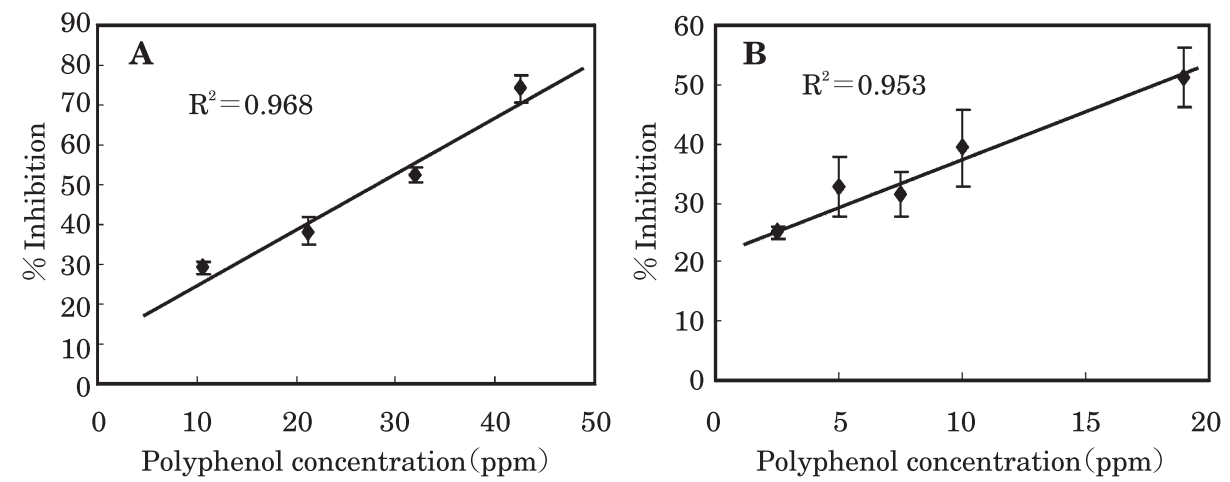

Fig. 1 Inhibition ratios (means; bars $=\mathrm{SD}$ ) of mouse $\alpha$-amylase activity (A) and $\alpha$-glucosidase activity (B) by Adzuki bean polyphenol

$\alpha$-Amylase is from porcine pancreas and $\alpha$-glucosidase is from bakers yeast.

市販の $\alpha$ - アミラーゼ酵素液に $10 \sim 45 \mathrm{ppm}$ の範囲で APP を添加したところ, 添加濃度に依存してアミラーゼ

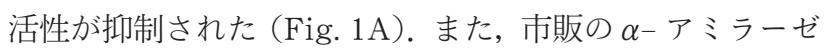
酵素液に LH20 カラムで調製した APP 亜画分; APP-E お よび APP-M を $20 \mathrm{ppm}$ 添加して活性を測定したところ, APP-E 添加による活性抑制はほとんど認められなかった
が， APP-M 添加により活性が 69.8土6.9\% 抑制された。ま た, マウス小腸内容物のホモジネートを酵素源として, APP を $20 \mathrm{ppm}$ まで添加して $\alpha$-アミラーゼ活性を測定し たところ，ポリフェノール濃度 $(\mathrm{X})$ と活性阻害率 $(\mathrm{Y})$ と の関係は $\mathrm{Y}=4.17 \mathrm{X}-6.40$ の式で表され, 添加濃度に比例 して活性が抑制された。 マウス小腸内容物に APP-E を 20 
ppm 添加しても $\alpha-$ アミラーゼ活性の抑制はほとんど認め られなかったが，同濃度の APP-M を添加すると，活性は $84.2 \pm 3.8 \%$ 抑制された。 また，マウス小腸粘膜ホモジネー トに APP を $20 \mathrm{ppm}$ 添加して $\alpha$-グルコシダーゼ活性を測 定したところ，顕著な活性抑制は認められなかった。しか し, 市販の $\alpha-$ グルコシダーゼ酵素液に $2.5 \sim 19.0$ ppm の 範囲で APP を添加したところ, 濃度依存的に活性抑制が

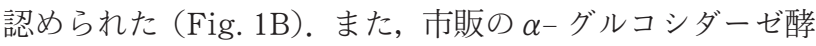
素液に APP-E 20 ppm 添加するとわずかに活性が抑制 $(0.8 \pm 4.0 \%)$ され，同濃度の APP-M を添加すると，活性は $49.1 \pm 2.4 \%$ 抑制された。 これらの結果は, APP, 特に亜画

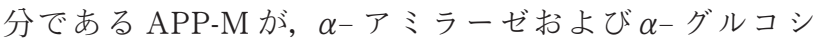
ダーゼ活性を抑制することを示唆している.

糖分解酵素の活性抑制剂を使用したヒト臨床試験では, 糖尿病予防や肥満に効果のあることが報告されている ${ }^{14)}$. 今回の実験結果から，APP はは血糖值上昇抑制作用执よ び糖分解酵素の活性抑制作用があり, 生活習慣病の予防に 有用であることが期待される.

\section{3. 要 約}

小豆ポリフェノール（APP）をマウスにゾンデで単回投 与して，その後，ジャガイモデンプン，ショ糖およびマル トースをそれぞれ与えると，すべてのマウス群の血中グル コース濃度はコントロール群に比べ有意に低い值を示し た。しかし，グルコースを与えた場合に有意差は認められ なかった。また，1日に与える APP 量を単回投与の約 $40 \%$ 量として 2 週間継続投与後, ショ糖を与えた場合に あ，血中グルコース濃度はコントロール群のそれに比べ有 意に低い值を示した。 ストレプトゾトシン誘発糖尿病マウ ス（STZ-DM）にAPP を単回投与してショ糖を与えると， 血中グルコース濃度はコントロール值よりも有意に低い值 を示した。 また, in vitro 実験により, APP の添加濃度に

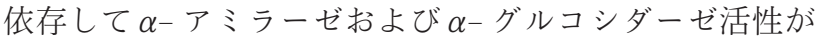
抑制されること，および APP 亜画分（APP-E および APPM）の特に APP-M が， $\alpha-$ アミラーゼおよび $\alpha-$ グルコシ ダーゼ活性を抑制することを明らかにした。これらの結果 は，APP による血糖值上昇抑制作用は，主に APP-M の糖 分解酵素の活性抑制作用に起因することを示唆している.

小豆エタノール抽出物を調製していただいた北海道立十 勝農業試験場の加藤淳主任研究員および北海道立中央農業 試験場の相馬ちひろ研究員に感謝します。この研究は日本 豆類基金協会の資金援助を受け，帯広畜産大学 21 世紀
COE プログラム研究の一環として行った。

\section{文献}

1）出口ヨリ子，長田邦子，内田和美，木村広子，芳川雅樹，工 藤辰幸，保井久子，綿貫雅章，グアバ葉熱水抽出物の $\mathrm{db} /$ $\mathrm{db}$ マウスにおける抗糖尿病効果执よびヒト飲用試験によ る食後血糖値上昇抑制効果，農化誌，72，923-93（1998）。

2) Teramoto, T., Oki, N. and Kusano, S., Mate leaf inhibits the activity of saccharide hydrolyzing enzymes and suppresses the increase in blood glucose levels after sugar loading in rats. J. Jpn. Soc. Nutr. Food Sci., 58, 1721 (2005).

3) Matsumoto, M., Ishigaki, F., Ishigaki, A., Iwashina, H. and Hara, Y., Reduction of blood glucose level by Tea catechin. Biosci. Biotech. Biochem., 57, 525-527 (1993).

4) Honda, M. and Hara, Y., Inhibition of Rat Small Intestinal Sucrase and $\alpha$-Glucosidase Activities by Tea polyphenols. Biosci. Biotech. Biochem., 57, 123-124 (1993).

5) Tanaka, S., Han, L.K., Zen, Y.N. and Okuda, H., Effects of flavonoid fraction from Ginkgo biloba extract on the postprandial blood glucose elevation in rats. Yakugakuzasshi, 124, 605-611 (2004).

6) Tormo, M.A., Gil-Exojo, I., Romero, T.A. and Campillo, J. E., Hypoglycaemic and anorexigenic activities of an $\alpha-$ amylase inhibitor from white kidney beans (Phaseolus vulgaris) in Wistar rats. Br. J. Nutr., 92, 785-790 (2004).

7）小嶋道之, 山下慎司, 西繁典, 齋藤優介, 前田龍一郎, 小豆 ポリフェノールの生体内抗酸化活性と肝臓保護作用，食科 工, 53, 386-392 (2006).

8) Wu, X., Beecher, G.R., Holden, J.M., Haytowitz, D.B., Gebhardt, S.E., Prior, R.L., Lipophilic and hydrophilic antioxidant capacities of common foods in the United States. J. Agric. Food Chem., 52, 4026-4037 (2004).

9) Rakieten, N., Rakieten, M.L. and Nadkarni, M.R., Studies on the diabetogenic action of streptozotocin. Cancer Chemother. Rep., 29, 91-98 (1963).

10）小高裕之，松尾隆夫，ストレプトゾトシン糖尿病ラットに 打ける二糖類水解酵素阻害剂 AO-128 の改善作用, 栄食誌, 45, 33-38 (1992).

11) Anderson, R.A. and Polansky, M.M., Tea enhances insulin activity. J. Agric. Food Chem., 50, 7182-7186 (2002).

12) Wu, L.Y., Juan, C.C., Ho, L.T., Hsu, Y.P. and Hwang, L.S., Effect of green tea supplementation on insulin sensitivity in Sprague-Dawley rats. J. Agric. Food Chem., 52, 643-648 (2004).

13) Waltner-Law, M.E., Wang, X.L., Law, B.K., Hall, R.K., Nawano, M. and Granner, D.K., Epigallocatechin gallate, a constituent of green tea, represses hepatic glucose production. J. Biol. Chem., 277, 34933-34940 (2002).

14) Lankisch, M., Layer, P., Rizza, R.A. and DiMagno, E.P., Acute postprandial gastrointestinal and metabolic effects of wheat amylase inhibitor (WAI) in normal, obese, and diabetic humans. Pancreas., 17, 176-181 (1998).

(平成 18 年 7 月 19 日受付，平成 18 年 10 月 16 日受理) 